\title{
Determination of Pentachlorophenol and Hexachlorobenzene in Natural Waters Affected by Industrial Chemical Residues
}

\author{
Vânia Gomes Zuin, Flavia Pereira da Silva Airoldi, Nádia Regina do \\ Nascimento, Maria Diva Landgraf, and Maria Olímpia de O. Rezende*
}

Instituto de Química de São Carlos, Universidade de São Paulo, C.P. 780, 13560-970 São Carlos - SP, Brazil

\begin{abstract}
Este trabalho teve como principal objetivo o desenvolvimento de uma metodologia para a análise simultânea de pentaclorofenol (PCP) e hexaclorobenzeno (HCB) em água natural de subsuperfície proveniente de uma região afetada por resíduos industriais (São Vicente-SP), onde a maior parte da população se utiliza de poços pouco profundos para o abastecimento. A extração líquido-líquido apresentou bons resultados quanto à recuperação e repetibilidade do método. Para o nível de fortificação de $10 \mathrm{ng} \mathrm{L}^{-1}$ de PCP e HCB a recuperação situou-se entre $81.5 \%$ e $103.0 \%$, com um desvio padrão relativo de $2.4 \%$ a $4.1 \%$. A determinação dos analitos foi efetuada por GC-ECD e/ou GC-MS. Adicionalmente, o limite de quantificação do método foi de $5 \mathrm{ng} \mathrm{L}^{-1}$ para PCP e $2 \mathrm{ng} \mathrm{L}^{-1}$ para $\mathrm{HCB}$, valores que estão abaixo do nível máximo permitido pelas diretrizes da Comunidade Européia para resíduos de pesticidas em água potável.

This paper presents the development of a methodology for the simultaneous analysis of pentachlorophenol and hexachlorobenzene in natural waters affected by industrial residues, as its principal goal. Samples were collected in Quarentenário, São Vicente city, where most of the population utilize wells for their supply. The liquid-liquid extraction employed to remove PCP and HCB from the matrix for further identification and quantification, showed very good recovery and repeatability. The recovery range was between $81.5 \%$ and $103.0 \%$, with a relative standard deviation of $2.4 \%$ and $4.1 \%$ for a fortification level of $10 \mathrm{ng} \mathrm{L}^{-1}$. In addition, organochlorine compounds were determined by GC-ECD and/or GC-MS. The limit of quantification was $5 \mathrm{ng} \mathrm{L}^{-1}$ for PCP and $2 \mathrm{ng} \mathrm{L}^{-1}$ for $\mathrm{HCB}$, which are below the maximum level allowed by the EC directives for pesticide residues in drinking water.
\end{abstract}

Keywords: pentachlorophenol, hexachlorobenzene, organochlorine compounds

\section{Introduction}

Natural waters are ultimately contaminated by inputs from all compartments of the environment. Effluents are discharged into rivers, lakes and seas, while superficial and ground waters receive leachates and run off from the land which is contaminated by industrial waste compounds ${ }^{1,2}$.

Organochlorine pollutants are formed in the course of many industrial processes as, for instance, pesticide manufacture. Compounds such as pentachlorophenol and hexachlorobenzene belong to a group of prioritary pollutants which are toxic to aquatic life and bioaccumulate in the tissue of biota exposed to contaminated waters ${ }^{3}$.

Organochlorine compounds are very soluble in organic solvents such as benzene, hexane, or isooctane. The lipophilic character increases with an increasing number of chlorine atoms in the molecule, thus contributing to the sorption of these pollutant compounds onto organic particles.

The lipophilicity has been described by $K_{o w}$, the partition coefficient in the octanol-water system. This parameter has been shown to be linearly correlated with partition coefficients between water and soil, sediment or biota 4 .

The use of $K_{o w}$ values to investigate the fate and the behavior of organic pollutants in rivers, lakes and estuaries has been reported ${ }^{5-7}$. Therefore, the biogeochemistry of chlorophenolics is expected to be different from other organic pollutants such as DDT, PCBs and HCB. The distribution of chlorophenolics is governed by both their hydrophilic and lipophilic properties. Xie et $a l^{8}$ have shown that the ionizable phenolic compounds are distrib- 
uted according to the distribuition ratio $(D)$ rather than $K_{\text {ow }}$. The distribuition ratio depends no only on the $\mathrm{pH}$ but also upon the dissociation constant $\left(K_{a}\right)$ and $K_{o w}$ and reflects the fate of the chlorophenols in the environment. As can be seen from a study of Abrahamsson and Ekdahl ${ }^{9}$, the effect is dramatic for the strongest acids. Consequently, at the $\mathrm{pH}$ encountered in sea water, pentachlorophenol and possibly 2,3,4,6-tetrachlorophenol will be transported mainly in their dissociated form.

The solubility in water changes depending on the acidity. This character is utilized for the analysis of chlorophenols, and also influences the toxicological properties ${ }^{10}$.

The toxic effect of organochlorine compounds seems to be linked to a chain reaction of their gradual dechlorination in body fluids and the formation of free radicals interfering with subcellular structures. Chronic toxicity studies have shown carcinogenic properties in some chlorinated inseticides, benzenes and phenols ${ }^{11-13}$. Chlorinated phenols are excreted from the organism mainly in urine, partially in the form of their sulphate and glucuronide conjugates ${ }^{14,15}$. Chlorophenols are known for their pronounced organoleptic characteristics ${ }^{16}$, the taste threshold ranging between 0.040-30 $\mu \mathrm{g} \mathrm{L}^{-1}$ and the smell threshold between 30$1600 \mu \mathrm{g} \mathrm{L}^{-1}$. This is important for setting their maximum tolerable concentrations in drinking water ${ }^{17}$.

A variety of procedures whose objective is the determination of organochlorine residues in water have been reported in the literature ${ }^{18-20}$. Several of them can be separated in three or four stages: (a) an extraction followed by; (b) a clean up, if necessary, with or without a derivatization step and; (c) the final determination by capillary gas chromatography with electron capture detection (GCECD).

In general, the preconcentration stage is based on liquid-liquid (LLE) or solid-phase extraction (SPE). A comparative study on the performance between SPE and LLE showed that the last method was more adequate for the extraction in waste waters or waters with high levels of organic matter ${ }^{21}$.

Some compounds, specifically chlorophenols, do not have favourable gas chromatographic properties due to their relative polarity, chemical reactivity and low vapour pressures, causing adsorption and tailing of the chromatographic peaks. This can be overcome to a large extent by derivatization, such as methylation, pentafluorobenzylation or acetylation, which have been used to determine low concentration levels of PCP in environmental samples by GC-ECD.

In this paper, we evaluated a method of simultaneous determination of PCP and HCB in natural waters from an industrial area of São Vicente, SP, southeast coast of Brazil, as a consequence of a serious contamination by industrial chemical residues.

\section{Experimental}

\section{Description of sampling area}

At least thirteen old chemical waste dumping sites are located on the São Paulo state coast. One of the largest has been recently discovered in Quarentenário, on the periphery of the city of São Vicente (Fig. 1) ${ }^{22}$. This suburban area is highly populated; and very close to a waste dumping site. The greatest problems, besides the direct contact with the contaminated environment, are the water coming from wells and the food (fruits, vegetables and chicken) grown in the region and used by the local population.

Quarentenário is located in the Mariana River basin, which is formed by fluvial and marine terraces interspersed by valley bottoms and basin zones. As it is an area in which processes of continental and marine natures coexist, the water dynamics are considerably complex. The existence of rivers with longitudinal profiles, weak gradient and not very competent flux besides the presence of porous materials on the surface make possible a better infiltration to the detriment of superficial flow. Soil is mainly Podzol kind, considerably permeable on the surface and unpermeable beneath, with hydrosoluble organic matter.

Atmospheric conditions show a predominant high air relative humidity (70-90\%) and pluviometric annual average between $2000-3000 \mathrm{~mm}, 70 \%$ corresponds to the summer months (October-March). The climate is tropical without any dry season, and the temperature average is over $25^{\circ} \mathrm{C}$ in the hottest month and $18^{\circ} \mathrm{C}$ in the coldest month ${ }^{22}$.

Subsuperficial water samples were collected along three toposequences (AQ, ED and FA) in Quarentenário, in January 1996, with the tutoring of geographer Nádia R. Nascimento (Departamento de Planejamento Regional UNESP - Rio Claro), and according to a previous study of geomorphological and pedological parameters involved in water dynamics ${ }^{22}$. Along each toposequence three stations were chosen according to distance from the waste dumping, sampled twice and the water was collected at different depths, respectively: Trench waters -TR1, 2 and 3 - (0.30 -

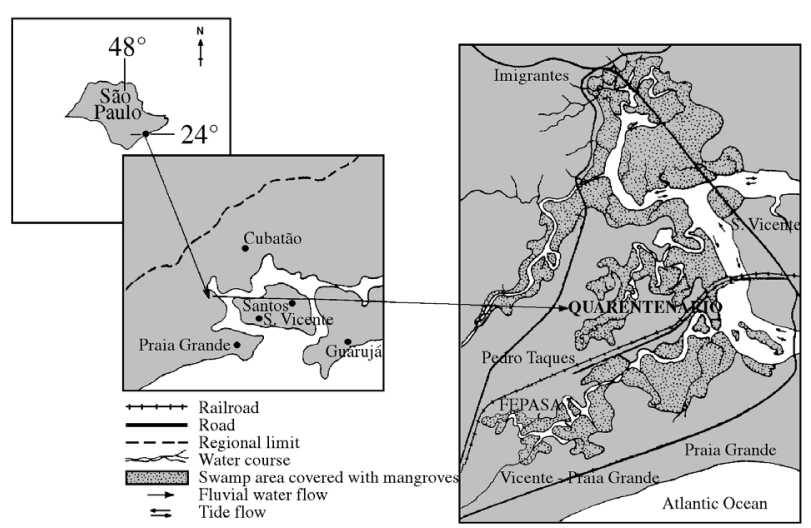

Figure 1. Map of sampling area. 
$0.80 \mathrm{~m})$ and well waters - WL1, 2 and 3 - $(8-4 \mathrm{~m})$. The notations TR1 and WL1 mean the closest to the waste dumping site, while TR3 and WL3 are the furthest from the site.

Temperature and $\mathrm{pH}$ were determined immediately and throughout the sampling. The water samples were stored in brown glass bottles $(1000 \mathrm{~mL})$ and transported under refrigeration. The determination of PCP and $\mathrm{HCB}$ was made shortly after the arrival of the samples in the laboratory ${ }^{23}$.

\section{Reagents and standards}

All reagents were of analytical grade (Merck, Rio de Janeiro - RJ, Brazil). Hexane was submitted to a chemical treatment and distilled before its use ${ }^{24}$. The PCP and HCB standards were obtained from Supelco (Supelco, Bellefonte, PA, USA).

Three standard solutions were used to spike the water for test purposes containing, respectively, 10, 20 and 200 $\mathrm{ng}$ of each compound $/ \mathrm{mL}$ of hexane. Aliquots of the stock solution were measured by using a $100 \mu \mathrm{L}$ syringe (701 RN, Hamilton Co., Reno - NV, USA).

\section{Apparatus}

All experiments were performed using a high resolution gas chromatograph (Hewlett Packard, model 5890 serie II, Palo Alto - CA, USA) equipped with a nickel-63 electron capture detector. Chromatographic data were collected and recorded using a HP Chemstation. A fused silica capillary column with $90 \%$ bis-cyanopropyl / $10 \%$ phenyl cyanopropyl polysiloxane phase (SP2330, Supelco, $30 \mathrm{~m}$ long $\mathrm{x}$ $0.25 \mathrm{~mm}$ id and with a film thickness of a $0.20 \mu \mathrm{m}$ ) was used with a split/splitless injector.

\section{Liquid-liquid extraction procedure}

$1000 \mathrm{~mL}$ of water were acidified by adding $2 \mathrm{~mL}$ concentrated $\mathrm{H}_{2} \mathrm{SO}_{4}$. Then, the compounds were extracted with $100 \mathrm{~mL}$ and two further $50 \mathrm{~mL}$ portions of hexane, respectively, in a separatory funnel.

The combined organic extract was dried with $\mathrm{Na}_{2} \mathrm{SO}_{4}$ and concentrated to approximately $1 \mathrm{~mL}$ in a rotatory evaporator.

\section{Derivatization procedure}

\section{Methylation using diazomethane solution}

One mililitre of a diazomethane solution (freshly prepared by distillation of $2.14 \mathrm{~g}$ de N-methyl-N-nitroso-ptoluenesulfonamide with $10 \mathrm{~mL} \mathrm{KOH} 96 \%$ in ethanol and $30 \mathrm{~mL}$ ethyl ether) was added to the standard or sample extract ${ }^{25}$. Then, the yellow mixture remained at room temperature for about $30 \mathrm{~min}$ for a complete methylation. The volume was reduced to $1 \mathrm{~mL}$ by evaporation under a gentle stream of $\mathrm{N}_{2}$.
Comparison between methylation and acetylation

One mililitre of PCP standard solution $40 \mu \mathrm{g} \mathrm{L}^{-1}$ was derivatizated according to the above method.

To promote acetylation, to $50 \mathrm{~mL}$ of milliQ water was added PCP standard solution. To this, it was added $0.25 \mathrm{~g}$ of $\mathrm{NaHCO}_{3}, 0.25 \mathrm{~mL}$ of acetic anhydride and $5 \mathrm{~mL}$ of hexane. The mixture was stirred vigorously for $60 \mathrm{~min}$ and, the organic phase containing the acetylated product, at $40 \mu \mathrm{g} \mathrm{L}^{-1}$ level, was determined by GC-ECD.

\section{Chromatographic conditions: determination of standard and sample extract}

A volume of $1 \mu \mathrm{L}$ of each standard or sample extract was injected under the following conditions: temperature injector: $280{ }^{\circ} \mathrm{C}$, temperature detector: $300{ }^{\circ} \mathrm{C}$, initial column temperature: $160{ }^{\circ} \mathrm{C}$ programmed at $1{ }^{\circ} \mathrm{C} \min ^{-1}$ to $230^{\circ} \mathrm{C}$. The carrier gas was $\mathrm{H}_{2}$ at an average linear velocity of $1 \mathrm{~mL} \mathrm{~min}^{-1}$. The split rate was $1: 15$ and the make up gas was $\mathrm{N}_{2}$ at $62.5 \mathrm{~mL} \mathrm{~min}{ }^{-1}$. The standard deviations of repeated injections $(n=5)$ were $\pm 0.05 \mu \mathrm{L}$. Quantitation was performed by using the external standard. Calibration graphs were constructed at concentrations between 5 and $200 \mu \mathrm{g} \mathrm{L}{ }^{-1}$, which presented good linearity, as indicated by correlation coefficients of 0.999 for PCP and HCB.

\section{Results and Discussion}

\section{Recovery studies}

Recovery studies with investigated compounds from spiked MilliQ water were done at three concentration levels. At each concentration level, five determinations were performed. The mean recoveries and relative standard deviations (R.S.D.) of PCP and HCB can be seen in Table 1.

To confirm its applicability, the extraction method was performed for natural water from São Vicente city, which had in general a relatively transparent aspect. Therefore, one litre of water sample previously analysed and free of PCP and HCB was spiked with these compounds at $20 \mathrm{ng} \mathrm{L}^{-1}$ level. The recoveries found were $80.0 \%$ for PCP and $83.2 \%$ for $\mathrm{HCB}$, similar to those obtained from MilliQ water. Previous experiments had shown that the type and

Table 1. Results of recovery experiments.

\begin{tabular}{lccc}
\hline Compound & $\begin{array}{c}\text { Concentration } \\
\text { level }\left(\mathrm{ng} \mathrm{L}^{-1}\right)\end{array}$ & $\begin{array}{c}\text { Mean } \\
\text { recoveries (\%) }\end{array}$ & $\begin{array}{c}\text { R.S.D., } \mathrm{n}=5 \\
(\%)\end{array}$ \\
\hline PCP & 10 & 81.5 & 2.4 \\
& 20 & 82.7 & 2.4 \\
& 200 & 97.5 & 2.1 \\
HCB & 10 & 103.0 & 4.1 \\
& 20 & 88.9 & 3.9 \\
& 200 & 98.5 & 4.0 \\
\hline
\end{tabular}


volume of solvent could increase the emulsion formation. The choice of hexane over a more polar solvent such as dichloromethane, and the addition of acid in natural water samples, limited this kind of problem.

The recovery results using solvent extraction were comparable to those obtained by Vidal et al. ${ }^{21}$, which showed that the LLE was more adequate than SPE for the determination of organochlorine pesticides in river water samples with high amounts of organic matter. These data do agree with the studies of $\operatorname{Tan}^{26}$ in which, despite the numerous claims by both manufactures and research groups on the usefulness of SPE cartridges, LLE was a more accurate alternative method for organochlorine pesticide residue determination in environmental waters.

Derivatization studies: comparison between methylation and acetylation

Diazomethane solution and acetic anhydride were compared as derivatizing agents. Acetic anhydride has the advantage of providing derivatization in situ. In the presence of $\mathrm{KHCO}_{3}$, chlorophenols in water are acetylated directly without pre-extraction ${ }^{27}$. However, the acetylation procedure was not found to be applicable to the lower nanogram per litre level of polyhalogenated phenols, like PCP. The results of PCP derivatization methods showed that the best recoveries and shortest time determination were obtained with diazomethane and not with acetic anhydride. In adition, HCB when present in standard solutions and extract samples, does not suffer any reaction during PCP derivatization.

Although the use of diazomethane solution requires care on handling, it is a simple and efficient derivatizing agent. The methyl derivative, pentachloroanisole, is stable in the dark at low temperature, whereas the PCP acetate is not, which makes the storage of sample extracts easier if they are methylated.

Also, no clean-up step is required after methylation, due to the low background observed upon the use of diazomethane solution. Figure 2 shows the chromatograms obtained with the utilization of diazomethane solution and acetic anhydride. As can be seen, the methylation reaction was better than acetylation.

\section{Determination of PCP and HCB in natural waters}

Table 2 presents the concentration levels of PCP and $\mathrm{HCB}$ in natural waters, the depths where water samples were collected and their $\mathrm{pH}$.

The environmental distribution and transport of most chlorinated compounds is described by their lipophilicity. Their lipophilicity, measured by the $K_{\text {ow }}$, implies that they can be adsorbed onto organic particles, such as water suspended particles. Since the phenolics are weak acids, their adsorption potentials are not only dependent on their lipophilicity but also strongly influenced by the $\mathrm{pH}$ of the

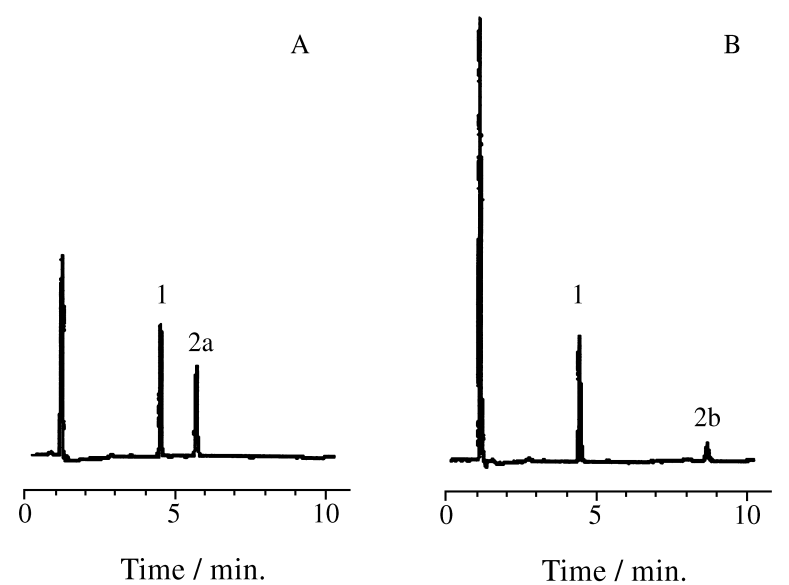

Figure 2. Gas chromatogram of PCP standard submitted to diferent derivatization reactions with (A) diazomethane and (B) acetic anhydride. $1 \mathrm{HCB}$ (4.46 min), 2a methylated PCP (5.68 $\mathrm{min})$ and $2 \mathrm{~b}$ acetylated PCP ( $8.90 \mathrm{~min})$. See text for experimental conditions.

Table 2. Concetration levels of PCP and HCB in natural waters.

\begin{tabular}{lcccc}
\hline Sample $^{\mathrm{a}}$ & Depths $(\mathrm{m})$ & $\mathrm{pH}$ & $\mathrm{PCP}\left(\mathrm{ng} \mathrm{L}^{-1}\right)$ & $\mathrm{HCB}\left(\mathrm{ng} \mathrm{L}^{-1}\right)$ \\
\hline AQTR1 & 0.49 & 4.2 & 8.5 & 311.7 \\
AQTR2 & 0.64 & 3.7 & 26.6 & 78.2 \\
AQTR3 & 0.55 & 3.9 & - & 19.7 \\
EDTR1 & 0.56 & 3.4 & - & - \\
EDTR2 & 0.47 & 3.5 & - & - \\
FATR1 & 0.78 & 4.1 & - & 2.3 \\
FATR2 & 0.70 & 3.3 & - & 3.8 \\
FATR3 & 0.54 & 4.1 & 5.5 & 2.0 \\
\hline
\end{tabular}

(-) Trench samples below limit of quantification (L.O.Q.).

${ }^{\mathrm{a}}$ All well samples (AQWL, EDWL and FAWL1,2,3) were below L.O.Q.

ambient water. Consequently, at the $\mathrm{pH}$ encountered in those natural waters, PCP could be transported mainly in its undissociated form and adsorbed on suspended particles $^{28}$.

The results indicated that PCP and HCB levels are directly related to the distance of the contaminated area. In a way, it should be evident that in adjacencies of the industrial dumping site the levels of PCP and HCB are higher due to the proximity of trenches in relation to the contamination source. As PCP and HCB are sligtly soluble in water, the possibility of migration would decrease with distance. The values found for the AQTR1 sample, and maybe for the AQTR2 sample, can be a result of a direct contamination occurred probably during the residue deposition. We point out that trench 1 of the AQ toposequence is just aproximately $10 \mathrm{~m}$ from the fence which isolates the waste dumping area. This would easily explain the direct contamination. 


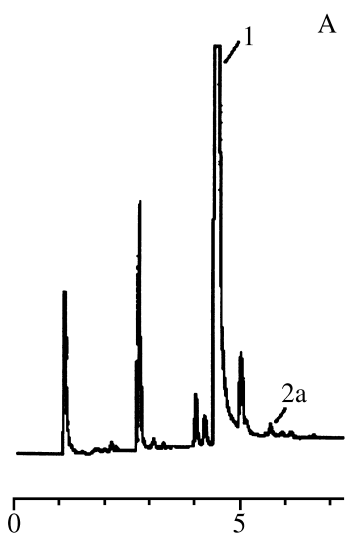

Time / min

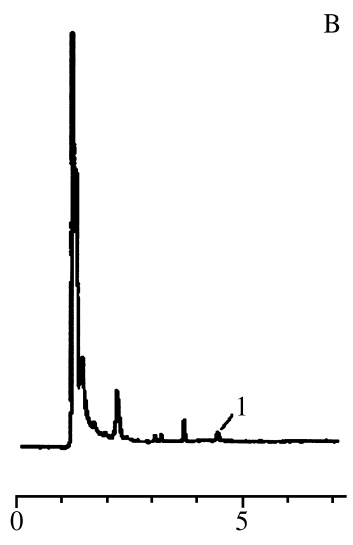

Time / min
Figure 3. Gas chromatogram of (A) AQTR1 and (B) FATR1 extract samples. $1 \mathrm{HCB}$ (4.46 min) and 2a methylated PCP (5.68 min). See text for experimental conditions.

On the other hand, the contamination by subsuperficial waters is also admitted, which would explain the fact of having determined PCP and HCB residues in more distant trenches. Although not determined, the transport would not occur only horizontally, but also in depth, taking organochlorine residues to well water.

In addition, a dilution factor appears to be in operation during rainy weather, which contributes to reduce the contaminants in well samples.

The chromatograms of AQTR1 and FATR1 extracts show the peaks corresponding to PCP and HCB (Fig. 3). Also, the identity of such compounds in sample extracts was established by GC-MS.

\section{Conclusions}

The method described here was suitable for simultaneous determination of PCP and HCB in natural waters at the nanogram per litre concentration level. The mean recoveries using LLE of investigated compounds from spiked MilliQ water were $87.2 \%$ for PCP and $96.8 \%$ for HCB. The derivatization procedure was discussed and methylation showed most adequate results, giving better recoveries and chromatographic characteristics. Despite the concentration levels of PCP and HCB in well samples being below the L.O.Q., it is evident that the studied area presents a critical situation, offering risks to different environmental compartiments and finally to the local population.

\section{Acknowledgments}

The authors are thankful to Brazilian financial agencies CAPES, FAPESP and CNPq, for supporting this work.

\section{References}

1. Cruz, I.; Wells, E.D. Anal. Chim. Acta 1993, 283, 280.
2.Puig, D.; Barceló, D. Chromatographia 1995, 40, 435.

3. Fing Ler, S.; Drevenkar, V.; Tkalcevic, B.; Smit, Z. Bull. Environ. Contam. Toxicol. 1992, 49, 805.

4. Kenaga, E.E.; Goring, C.A.I. In Aquatic Toxicology: Proceedings of the Third Annual Symposium in Aquatic Toxicology, Eaton, J.G., Ed.; Philadelphia, 1980 , p.78.

5. Lopez-Avila, V.; Hites, R.A. Environ. Sci. Technol. 1980, 14, 1382.

6. Wegman, R.C.C.; Van den Brook, H.H. Water Res. 1983, 17, 227.

7. Paasivirta, J.; Sakka, J.; Leskijarvi, T.; Roos, A. Chemosphere 1980, 9, 441.

8.Xie, T.M.; Abrahamsson, K.; Folgelqvist, E.; Josefsson, B. Environ. Sci. Technol. 1986, 20, 457.

9. Abrahamsson, K.; Ekdahl, A. J. Chromatogr. 1993, 643, 239.

10. Veningerová, M.; Prachar, V.; Kovacicová, J.; Uhnáh, J. J. Chromatogr. 1997, 774, 333.

11. Hougton, D.L.; Ritter, L. J. Am. Coll. Toxicol. 1995, 14,71 .

12. Millikan, R.; Devoto, E.; Newman, B.; Savitz, D. Beast Cancer Res. Treatment 1995, 35, 79.

13. WHO, Lindane, Environmental Health Criteria, $\mathrm{N}_{\mathrm{O}}$. 124, ICPS, Geneva, 1991.

14. Vasilic, Z.; Fi ng Ler, S.; Drevenkar, V. Fresenius J. Anal. Chem. 1991, 341, 732.

15. WHO, Pentachlorophenol, Environmental Health Criteria, No. 71, ICPS, Geneva, 1987.

16. Crosby, D.J.; Beynon, K.I.; Greve, P.A.; Korte, F.; Still, G.G.; Vonk, J.W. Pure \& Appl. Chem. 1981, 53, 1051.

17. WHO, Guidelines for Drinking Water Quality, Vol. 1: Recomendations. Geneva, 1993.

18. Cruz, I.; Wells, E.D. Inter. J. Environ. Anal. Chem. 1992, 48, 101.

19. Tomkins, A.B.; Merriweather, R.; Jenkins, R.A. J. Assoc. Off. Anal. Chem. 1992, 75, 1091.

20. Quayle, W.C.; Jepson, I.; Fowlis, I.A. J. Chromatogr. 1997, 773, 271.

21. Vidal, L.H.; Trevelin, W.R.; Landgraf, M.D.; Rezende, M.O.O. Intern. J. Environ. Anal. Chem. 1994, 56, 23.

22. Nascimento, N.R. In: Estudo da dinâmica do escoamento das águas em superfície e subuperfície e dos materiais a ele associado, utilizando parâmetros geomorfológicos e pedológicos - Bacia do rio Mariana - SP; Relatório Técnico: DPR - IGCE - UNESP; Rio Claro, 1995.

23. Jeanot, R. Intern. J. Environ. Anal. Chem. 1994, 57, 231. 
24. Perrin, D.D.; Armarego, L.F. Purification of Laboratory Chemicals; Pergamon; Oxford, 1980. p. 557.

25. Vogel, A.I. Vogel's textbook of practical organic chemistry; Longman Scientific \& Technical; 5th ed., Essex, 1989, p. 430.
26. Tan, G.H. Analyst 1992, 112, 1129.

27. Lee, H.; Weng, L; Chau, A.S.Y. J. Assoc. Off. Anal. Chem. 1994, 67, 789.

28. Airoldi, F.P.S.; Zuin, V.G.; Landgraf, M.D.; Rezende, M.O.O. J. Environ. Sci. Health, Part B. (submitted for publication).

Received: July 1, 1998 